Rabaska

Revue d'ethnologie de l'Amérique française

\title{
La Mission de folklore musical en Basse-Bretagne de 1939
}

Volume 8, 2010

URI : https://id.erudit.org/iderudit/045264ar

DOI : https://doi.org/10.7202/045264ar

Aller au sommaire du numéro

Éditeur(s)

Société québécoise d'ethnologie

ISSN

1703-7433 (imprimé)

1916-7350 (numérique)

Découvrir la revue

Citer ce document

(2010). La Mission de folklore musical en Basse-Bretagne de 1939. Rabaska, 8 , 143-143. https://doi.org/10.7202/045264ar d'utilisation que vous pouvez consulter en ligne.

https://apropos.erudit.org/fr/usagers/politique-dutilisation/ 
Points de vue / livre

\section{La Mission de folklore musical en Basse-Bretagne de 1939}

Les Archives de la Mission de folklore musical en Basse-Bretagne de 1939 du Musée national des arts et traditions populaires par Claudie Marcel-Dubois et l'abbé François Falc'hun assistés de Jeannine Auboyer. Éditées et présentées par Marie-Barbara Le Gonidec avec la collaboration de Michel Valière, Yves Defrance, Gilles Goyat, Christophe Fouin et Silvia Pérez-Vitoria. Paris, Éditions du Cтно, et Rennes, Dastum, 2009, «La librairie des cultures » $n^{\circ} 3,443$ p. + DVD ISBN 978-2-7355-0704-7

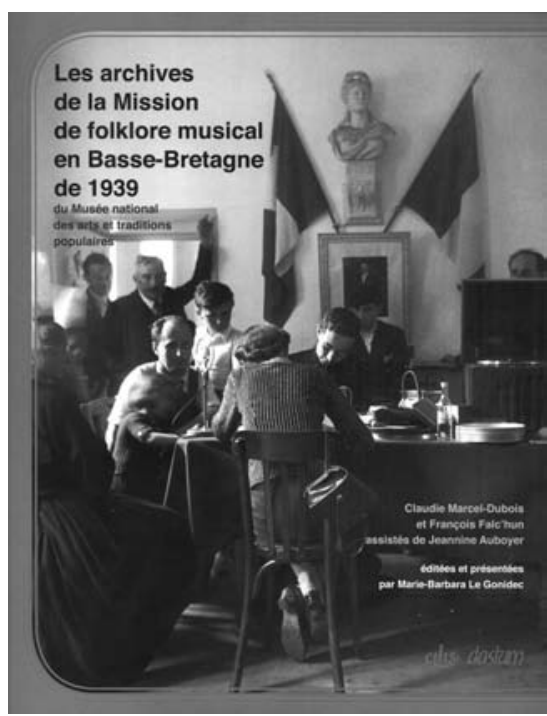

